\title{
The Role of Critical Thinking as a Mediator Variable in the Effect of Internal Locus of Control on Moral Disengagement
}

Tahrir

Universitas Islam Negeri Sunan Gunung Djati, Indonesia, tahrir@uinsgd.ac.id

\section{Farid Soleh Nurdin}

Universitas Islam Negeri Sunan Gunung Djati, Indonesia, farid.s.nurdin@uinsgd.ac.id

Ida Royani Damayanti

Sekolah Tinggi Ilmu Sosial dan Ilmu Politik, Indonesia, idamayanti.s3.yai@gmail.com

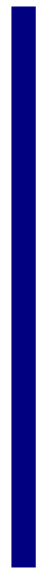

The background of this research is the inconsistency of the results of previous research about the factors that influence moral disengagement. This study aims to determine the role of critical thinking as a mediator of the influence of internal locus of control on student moral disengagement. The population in this study were 1560 students of the State Islamic University (UIN) Sunan Gunung Djati Bandung who lived in boarding schools around the campus with a total of 300 respondents taken randomly. Data collection uses internal locus of control (ILoC), critical thinking (CT), and moral disengagement (MD) scales. Based on structural test results it is known that internal locus of control has a positive and significant effect on critical thinking, internal locus of control has a negative and significant effect on moral disengagement, and critical thinking has a negatif and significant effect on moral disengagement. The results of the model test with structural equation model (SEM) show that critical thinking plays a negative and significant role as a mediator between the influence of internal locus of control on moral disengagement.

Keywords: internal locus of control, critical thinking, moral disengagement, moral, role

\section{INTRODUCTION}

Moral is a term that is very popular in society in relation to social life. Morals usually refer to the assessment of human behavior in their daily lives. Someone will be said to be moral if his behavior is in accordance with the values and rules that have been applied to a particular society and vice versa if someone behaves not in accordance with the values and rules it will be called an immoral human being. The study of morals has actually been done for centuries by experts and until now studies of morals have not 
seen any signs of stopping. The study of morals continues because morality has a very important role for humans in their lives.

The word 'moral' actually comes from Greek, namely mores, which means habits, procedures, and customs behave. According to Suseno (1998) moral refers to the good and bad of a human being as human being. According to Hazlitt (2003) moral is a little sacrifice of good for the greater good. While according to Sternberg (1994) moral refers to the concept of good human relations with each other. Huky (1982) has formulated a moral understanding more comprehensively, namely morality: 1) a set of ideas about behavioral guidelines held by a group of people in the environment. 2) Teachings about behavior based on certain views of life or religion. 3) Human behavior based on awareness in accordance with the values and norms that apply in their environment.

According to Edwards (1967) moral means: 1) beliefs about human nature, 2) beliefs about ideals, 3) beliefs about what is good for pursuing self-interest, 4) rules about what should be done and 5) motives that encourage people to choose the right or wrong path.The moral word actually comes from Greek, namely mores, which means habits, procedures, and customs behave. According to Trevino, Weaver, and Reynolds (2006) moral behavior is a behavior that is conform to values, procedures, and rules that are generally accepted in a society. This means that moral behavior will appear if someone is in a social environment or living in a society. Moral in essence is a set of values and procedures for behaving for humans who must be obeyed to achieve prosperity in life. Therefore, behavior that does not follow the values agreed upon by the community will be called immoral behavior.

Referring to the above understanding, morality for human has a role as a frame of reference in behaving to realize a dignified human being. According to Sigelman, Carol and Elizabeth (2003) moral functions for humans are: 1) differentiating right and wrong, 2) guidelines for behaving in every situation, and 3) for feeling happy when doing right and feeling embarrassed when doing wrong. Based on the opinions of Sigelman, Carol and Elizabeth (2003), it can be understood that moral is a guideline to behave so that humans can feel the impact of their actions which are happy or suffering.

Furthermore Sigelman, Carol and Elizabeth (2003) divide morals into 3 components, namely affective, cognitive, and behavior. Affective components are concerns and feelings of guilt that move human thoughts and actions to act according to moral principles. The cognitive component is a way of conceptualizing right and wrong and for making decisions about how individuals should behave. Components of behavior are behavioral forms that are truly moral. However, although moral has a very important role for human life, in fact there are still many people who consciously behave not based on moral values with various reasons to benefit themselves.

In the concept of Bandura (2016) behavior that is not based on moral values with the aim of self-interest is called moral disengagement. According to Bandura (2016) moral disengagement is a mechanism of cognition in a person to justify unethical or immoral behavior. According to Detert, Sweitzer and Trevino (2008) moral disengagement is the process by which individuals make unethical moral decisions when self-regulation is 
deactivated through several interrelated collective cognitive mechanisms. According to Hyde, Shaw and Moilanen (2009) moral disengagement is a process when one moral belief or values justifies anti-social behavior, and there is a lack of dissonance or obstacles in the anti-social action. According to Bandura (2016) moral disengagement is realized through eight strategies or mechanisms: diffusion of responsibility, displacement of responsibility, euphemistic labeling, advantageous comparison, distortion of consequences, dehumanization of victims, attribution of blame, moral justification.

Moral disengagement has a serious influence on human life, as the results of research Iwai, Carvalho, and Lalli (2018) found that moral justification and displacement of responsibility create a higher desire to behave immorally compared to think about the consequences. Likewise, Hsu and Pan's (2018) study of 282 and 336 middle school students in physical education classes found that the moral disengagement strategy (advantageous comparison and non-responsibility) positively predicted four bad behaviors (i.e. low involvement, failure to follow directions, poor self-management, and disturbing behavior). While the experimental research conducted by Tillman, Gonzalez, Whitman, Crawford, and Hood (2018) on 182 respondents showed that individuals who are morally disengaged from unethical actions will experience negative emotions after knowing the consequences. In addition, it was also found that guilt and shame were related to moral disengagement. The results of Fida, Tramontano, Paciello, Guglielmetti, Gilardi, Probst and Barbaranelli (2018) research show that being the target of workplace aggression (dehumanization moral behavior management from third parties) not only affects health symptoms but also affects bad behavior.

According to Cherry (2006) internal locus of control allows individuals to direct, assess, and accept responsibility in behaving ethically. This is evidenced by the research of Moore, Detert, Trevino, Baker, and Mayer, (2015) who found that moral disengagement was positively correlated with dishonesty, cynical personality, the center of external selfcontrol. Likewise, the results of the Ogunyemi (2013) study show that external locus of control can improve unethical behavior even though internal locus of control is also not a guarantee for individuals to behave ethically. The results of Chiu's (2003) study also found that managers who have an internal locus of control are more consistent in their assessment and moral behavior compared to managers who have external locus of control.

However, the research of Detert, Travino and Sweitzer (2008) found that internal locus of control and external locus of control power did not correlate significantly with moral disengagement. Likewise, the results of Aprilia and Solecha (2012) show that internal locus effort is a significant factor in influencing moral disengagement, but internal locus ability is a non-significant factor in influencing moral disengagement.

According to Rotter (quoted Karimi and Alipour, 2011) internal locus of control in people who believe that their results, successes and failures are the result of their own actions and efforts. According to Kreitner and Kinicki (2009) individuals who have an internal locus of control tendency are individuals who have the confidence to be able to control all events and consequences that have an impact on their lives. 
According to Hanurawan (2010) people with internal locus of control are very suitable for occupying positions that require initiative, innovation, and behavior initiated by oneself such as researchers, managers or planners. Individuals with internal locus of control have a perception that the environment can be controlled by themselves so they are able to make changes according to their wishes.

According to O'Fallon and Butterfield (2005) people with internal locus of control tend to show an intention to behave unethically but are more likely to show intention to behave ethically. Conversely, people with external locus of control have also been shown to have a higher level of moral release (Detert, Travino and Sweitzer, 2008). People with internal locus of control are more likely to behave ethically because they are people who like to work hard, have high initiative, always try to find problem solving, try to think as effectively as possible, and have a perception that effort must be made if they want to succeed (Crider 1983).

Based on the contradictions of the results of previous studies related to the factors that influence moral disengagement, researchers are interested in conducting research on factors that really affect moral disengagement. Researchers suspect that locus of control is not strong enough to influence moral disengagement because there are still inconsistencies in the results of the research mentioned above.

Based on the contradictions of the results of the researchers mentioned above, in this case the researcher wants to conduct research on internal locus of control, critical thinking and moral disengagement. Moral disengagement in this study is an endogenous variable, critical thinking as a mediator variable, and endogenous internal locus of control variable. Researchers place critical thinking variable as a mediator variable because based on a review of the results of previous studies, researchers found that to know the effect of internal locus of control on moral disengagement is always direct. Whereas from the results of previous studies found contradictions where several studies found that internal locus of control had a significant effect on moral disengagement, while other studies found that internal locus of control had no significant effect on moral disengagement.

The reason researchers put critical thinking as a mediator variable is based on the experimental research of Bustamante and Chaux (2014) on 116 class 9 adolescents with an average age of 14.6 years, which concluded that critical thinking and peer regulation can reduce moral disengagement with an F: 2.16 and p; 0.049. This study also showed a significant decrease in the moral disengagement aspects of the euphemistic language with F: 1.09 and p; 0.021, advantageous moral disengagement aspects comparisons with F: 1.92 and p: 0.036 , and moral disengagement cheating aspects with $F$ : 0.58 and p: 0.011 .

\section{THEORY OF THE STUDY}

\section{Internal Locus of Control}

According to Rotter (1966) internal locus of control refers to people who believe that their successes and failures are the result of their own actions and efforts. According to 
Kreitner \& Kinicki (2009) individuals who have an internal locus of control tendency are individuals who have the confidence to be able to control all events and consequences that have an impact on their lives. Whereas according to Robbins and Judge (2008) individuals who have high internal locus of control believe that they are the holders of control over whatever happens to them. Karimi and Alipour (2011) suggest that individuals with internal locus of control believe that they are able to control and manage their own lives by making decisions about these events.

Individuals with high internal locus of control can accept that achievement and failure depend on their own efforts and have the ability to determine their own results and be responsible for what happens (Karimi and Alipour, 2011). According to Hanurawan (2010) individuals with internal locus of control are very suitable for occupying positions that require initiative, innovation, and behavior initiated by oneself such as researchers, managers or planners. Individuals with internal locus of control have a perception that the environment can be controlled by themselves so they are able to make changes according to their wishes.

According to Hill (2011) individuals with internal locus of control have the following characteristics: 1) Experiencing greater personal well-being. The study found that internal locus was more confident, had a higher level of self-esteem than externals locus, succeeded in assignments, was less susceptible to depression, in stressful situations easier to recover, less prone to suicide, and experienced low anxiety. 2) Having a high motivation and good performance. Studies of individuals with internal locus of control show that they are hardworking, not easy to give up on problems, use time more efficiently, and show high motivation in work. 3) Shows superior cognitive function.

According to Hill (2011) individuals with high internal locus of control also show a higher level of functional intelligence, actively conduct information searches, are able to use cognitive organizational strategies for problem solving, have foresight in planning, are able to overcome helplessness, are more logical in mindset, not using stereotypes in thinking, having verbal fluency and better communication skills, and having better memories.

According to Crider (1983) the characteristics of internal locus of control are as follows: love to work hard, have high initiative, always try to find problem solving, always try to think as effectively as possible, always have a perception that effort must be made if you want to succeed. Rotter (1966) suggests that individuals with internal locus of control tend to perceive skills (abilities), abilities (abilities), and effort (effort) to determine what they get in their lives. Internal oriented individuals are more active and always try to master the life they live compared to external oriented individuals. The results of the research by Oğuzl and Sariçam (2015) show the opposite results that external locus of control is negatively significant with critical thinking.

The results of the Cherry (2006) study show that internal locus of control allows effective leadership, good moral judgment, accept responsibility and act ethically. Chiu's research (2003) also found that managers with internal locus of control showed consistency between moral judgment and moral actions rather than managers with 
external locus of control. Even so, individuals who have an internal locus of control will not automatically guarantee that they behave ethically, but that ability will make it easier for individuals to go against the flow if they have the desire to change their state of being positive. In their study of locus of control and moral disengagement, Detert, Sweitzer and Trevino (2008) found that people with external locus of control tended to blame external factors and spread responsibility to others. With this study Detert, Sweitzer and Trevino (2008) concluded that individuals with external locus of control were more likely to carry out higher moral disengagement than individuals with internal locus of control.

\section{Critical Thinking}

According to Suryosubroto (2009) critical thinking is a mental process for analyzing information obtained. This information is obtained through observation, experience, communication, or reading. Critical thinking is a systematic process that allows individuals to formulate and evaluate their own beliefs. According to John Chaffe (as quoted by Johnson, 2010) critical thinking is defined as thinking to systematically investigate the thought process itself. It means not only thinking deliberately, but also examining how we and others use evidence and logic. While according to (Desmita, 2010) critical thinking is the ability to think logically, to apply this to assessment of situations, and to make good judgments and decisions.

According to Özkahraman and Yıldırım (2011) critical thinking is an intellectual process by making concepts, implementing, synthesizing, and or evaluating information obtained from observation, experience, reflection, thought or communication as a basis for believing and taking action. Whereas according to Helpern (2011) reveals that critical thinking is the use of cognitive skills or strategies that increase the probability of the desired results. The types of critical thinking are problem solving, formulating conclusions, calculating possibilities, and making decisions, when thinkers use wise and effective skills towards certain contexts and types.

Critical thinking is a part of practical skills, which can help an individual in solving a problem. According to Desmita (2010) this critical thinking ability has certain characteristics that can be done and understood by each individual. Seifert and Hoffnung (1994) mention several components of critical thinking, namely: 1) Basic operations of reasoning. To think critically, a person has the ability to explain, generalize, draw deductive conclusions and formulate other logical steps mentally. 2) Domain-specific knowledge. In dealing with a problem, one must know about the topic or content. To solve a personal conflict, one must have knowledge of the person and who has the conflict. 3) Metacognitive knowledge. Effective critical thinking requires a person to monitor when he tries to truly understand an idea, realizes when he needs new information and invents how he can easily gather and study that information. 4) Value, beliefs and dispositions. Thinking critically means making a fair and objective assessment. This means there is a kind of self-confidence that thinking really leads to a solution. This also means there is a kind of persistent and reflective disposition when thinking. 
According to Facione, Facione, and Giancarlo (2000) critical thinking consists of seven aspects, namely: 1) Confidence is the level of trust that is held when doing reasoning. 2) Truth seeking is a desire to seek truth, dare to ask questions, and be honest and objective. 3) Analyticity is an awareness of potentially problematic situations and anticipates possible outcomes or consequences. 4) Systematicity is the ability to carry out organized, orderly, focused, and diligent investigations. 5) Open mindedness is the ability to think openly. 6) Inquisitiveness is a desire to know and understand something in depth. 7) Maturity is the ability to think carefully.

\section{Moral Disengagement}

Bandura (1999) states that basically every individual has a moral standard that serves to assess what is right and wrong in behavior. Besides that, each individual has selfregulation that plays a role in monitoring the behavior and conditions in which the behavior arises, assessing its relationship with moral standards, and regulating behavior based on the consequences that will occur (Bandura, 1999). The non-functioning of the moral standard as an internal regulator in regulating behavior causes individuals to behave unethically or often referred to as moral disengagement (Bandura, 1999).

According to Bandura (1999) moral disengagement is a term from social psychology to describe the process of convincing oneself that ethical standards do not apply to oneself in certain contexts. Detert, Sweitzer and Trevino (2008) moral disengagement is a process whereby individuals make an unethical decision when self-regulation is deactivated through the use of several interrelated collective cognitive mechanisms. According to Hyde, Shaw and Moilanen (2010) moral disengagement is one process when one moral belief or values justifies anti-social behavior, there is a lack of dissonance or obstacles to being involved in antisocial actions so that the action is acceptable.

Moral disengagement is a mechanism of cognition that occurs in individuals to justify immoral, unethical and anti-social behaviors. Individuals make logical reasons that are acceptable to common sense to justify immoral behavior, so that it seems that their immoral behavior is justified and avoids guilt. When moral disengagement occurs, individuals involve the process of reframing cognition of destructive behavior so that immoral behavior can be accepted without changing moral behavior or standards.

According to Bandura (2016) disengagement morals will not occur if individuals have effective self-regulation, because self-regulation as a process of regulating morality has two main functions, namely self-monitoring and affective as evaluative. In relation to moral disengagement self-monitoring is a locus to interpret whether an action is harmful or not, minimize errors, and prevent harmful behavior. Furthermore, the effectiveness of individual self-monitoring is very dependent on moral standards, where moral standards play a role as an assessor whether an action is right or not. Moral standards possessed by individuals are usually formed from social environments such as moral standards that have been described and written by influential community leaders. And affective evaluative functions to evaluate affection for right or wrong actions, especially for someone who has an emotional attachment. 
Bandura (2016) states that moral disengagement occurs through eight mechanisms, namely: 1) Moral justification is a process whereby an individual does not act morally on himself or others, but the process of action seems morally justified. In this mechanism individuals commit immoral acts for noble or noble purposes so that as if these actions cannot be blamed. For example, someone steals on the grounds that he wants to support his family. 2) Euphemistic labeling, is the process of someone using verbal language or finer expressions so that immoral behavior looks good. For example a doctor does not "kill" his patient but "eliminates the suffering" of his patient. 3) Advantageous comparison, is the process of comparing a moral violation with someone else's moral violations that are heavier, so that the individual can justify himself. For example, someone compares between a cocoa thief and a crime committed by a larger corruptor. 4) Displacement of responsibility, is the act of individuals who do not want to be blamed for responsibility because there is someone who has more authority. The individual throws responsibility for immorality to the authority because he feels that doing the deed is ruled by the pinna or someone else. For example, a student does not do class picking blaming his mother who does not wake up so oversleep when entering class. 5) Diffusion of responsibility, an individual feel that mistakes are not only done by himself but also by others. An individual obscure the responsibility of an immoral act because it is carried out together with other people. For example, a student does not feel guilty when making a brawl because it is done together with his friend. 6) Distortion of consequences or very little effort to reduce the consequences of injuring others. The individual simply ignores the responsibility of his immoral actions, so he does not need to feel guilty. For example, a mother will do anything for her child and not think of herself. 7) Attribution of blame, someone always blames the other party for his immorality or claims that he is a victim so he feels innocent. For example, someone commits an act of rape because the victim uses clothes and behaves seductively. 8) Dehumanization is an inhuman act of someone who is a victim. For example, a bigbodied child mocks, asks for money for a smaller person, or a senior who often interferes with his younger siblings.

\section{METHOD}

This study applied a quantitative approach with data analysis techniques using structural equation model (SEM) structural equation models. Respondents in this study were UIN Sunan Gunung Djati Bandung students who lived in Islamic boarding schools with a campus of 1560 people, and in this study a sample of 300 people, consisting of 140 males and 160 females who were on average 20 years old. The sampling process in this study was carried out in a simple random manner, where the researchers collected all the populations then taken samples from the population randomly.

The instrument used in this study is a scale that is modified from the instruments that have been made by experts. a modified instrument before use, then carried out a trial of a number of 200 respondents who were different from the research sample, but had the same characteristics. The internal locus of control instrument used in this study is a instrument modified from the Academic Locus of Control (ALC) instrument made by Trice (2013). Researcher's in making internal locus of control instruments, take the main 
idea of items an academic locus of control instrument made by Trice (2013). Then researchers make items that are completely different discussed with the culture and characteristics of the research subject. Researchers made modifications to the statement and addition of items, but alternative choices of answers were not modified. Before modifying the ACL instruments there were 28 items and after being modified, they were 29 items with 5 options, namely (very inappropriate), (inappropriate), (quite appropriate), (appropriate), and (very suitable). The results of the CFA analysis of internal locus of control instruments are known to have 25 valid items and the remaining 4 items are invalid, while the reliability test results show that the reliability coefficient is 0.98 .

The critical thinking (CT) variable is measured by a measurement tool developed from the California Critical Thinking Dispositions Inventory (CCTDI) measuring tool compiled by O'Hare (2004). The researcher in making critical thinking instruments, took the main idea from the critical thinking measurement items made by O'Hare (2004). Then researcher made completely different items that were discussed with the culture and characteristics of the research subjects because of cultural differences. Researcher modified the instrument by adjusting sentence editorial and item reduction. Before modifying the CCTDI instrument, there were 75 items and after modification there were 28 items, because it must be discussed with the culture and characteristics of the research subject. Researchers make critical thinking instruments with 5 options with 5 options, namely (very inappropriate), (not suitable), (quite appropriate), (appropriate), (very suitable). The results of the CFA analysis of CT measuring instruments are known to have 24 valid items and the remaining 4 items are invalid, while the reliability test results of the CCTDI measuring instrument obtained a reliability coefficient of 0.96 .

The moral disengagement (MD) variable was measured by a measuring instrument developed from a moral disengagement (MD) measure compiled by Detert, Sweitzer and Trevino (2008). The researcher in making moral disengagement instruments, took the main idea from the moral disengagement measurement items made by Detert, Sweitzer and Trevino (2008). Then researcher made completely different items that were discussed with the culture and characteristics of the research subjects because of cultural differences. Because of cultural differences the researchers modified the measuring instrument by adjusting sentence editorials and adding items. Before the modification of MD, instruments consisted of 32 items and after being modified there were 34 items with 5 options, namely (very inappropriate), (not appropriate), (quite appropriate), (appropriate), (very suitable). The results of the CFA analysis of MD measuring instruments found that 29 items were valid and the remaining 5 items were invalid, while the reliability test results of MD measuring instruments obtained a reliability coefficient of 0.99 .

The statistical analysis model that the researchers used in this study was a structural equation analysis (SEM) model with the help of software lisrel 8.7. This analytical model the researcher uses because the direct influence between variables and indirect effects needs to be found. 


\section{FINDINGS}

\section{Respondent Demographic Data}

Demographic data of respondents in this study can be seen based on gender, age, faculty origin and semester level.

Table 1

Distribution of Respondents by Gender and Age

\begin{tabular}{|c|c|c|c|c|c|}
\hline Gender & & Total & Age & & Total \\
\hline Male & Female & & $17-20$ & $21-24$ & \\
\hline 140 & 160 & 300 & 165 & 135 & 300 \\
\hline
\end{tabular}

Table 1 shows the total respondents about 300, 140 males and 160 females. Based on age level, it was found that respondents aged 17-20 years old amounted to 165 people and ages 21-24 were 135 people.

\section{Descriptive Analysis Results}

\section{Internal locus of control}

Based on the results of the study, it can be described that the average value of the internal locus of control variable is 82.77 , median 81.5 mode 75 , standard deviation 9.33 , variant 87.04 , minimum value 60 and maximum value 60 . Next to determine the high and low score of the internal locus of control respondents, researchers make norms with three categories, namely the score $\geq 92.10$ including the high category, the score of $73.45-92.09$ is in the moderate category, while the score $\leq 73.44$ is in the low category. Based on the above categorization, the following data are obtained:

Table 2

Norm Table of Internal Locus of Control

\begin{tabular}{lllcc}
\hline Category & Criteria & Score & Total & Percentage \\
\hline High & $\overline{\mathrm{x}}+\mathrm{SD}$ & $\geq 92,10$ & 46 & $15,41 \%$ \\
Middle & $\overline{\mathrm{x}}$-SD $-\overline{\mathrm{x}}+\mathrm{SD}$ & $73,45-92,09$ & 210 & $69,81 \%$ \\
Low & $\overline{\mathrm{x}}$-SD & $\leq 73,44$ & 44 & $14,78 \%$ \\
\hline Total & & & 300 & $100 \%$ \\
\hline
\end{tabular}

Based on table 2 it is known that respondents with a high internal locus of control were 46 people $(15.41 \%)$, respondents with moderate internal locus of control were 210 (69.81\%), and respondents with low internal locus of control were 44 people (14.78\%).

Furthermore, the researchers conducted tests whether differences in gender, age, school origin, semester level, and faculty origin played a role in improving the behavior of internal locus of control using the crosstab test. Based on the results of the Chi Square Test, it is known that the respondent's gender plays a significant role in determining the level of internal locus of control because the value of $p=0.005<0.05$. The age of respondents did not play a significant role in increasing or decreasing internal locus of control because the value of $p=0.216>0.05$. Likewise, the origin of school also does not have a significant role in raising and decreasing internal locus of control because the value of $p=0.0,089>0.05$. The semester level also does not play a significant role in increasing and decreasing internal locus of control because the value of $p=0.474>0.05$. 
Likewise, the origin of faculty does not play a significant role in increasing and decreasing the internal locus of control of respondents because the value of $p=0.0,922>$ 0.05 .

\section{Critical thinking}

Based on the results of the study, the critical thinking variable has an average value of 75.41 , median 75 , mode 73 , standard deviation 7.19 , variant 51.738 , minimum value 52 and maximum value 102. Furthermore, to determine the respondent's critical thinking score, hence researchers make norms with three categories as follows:

Table 3

Categorization of Critical Thinking

\begin{tabular}{lllll}
\hline Category & Criteria & Score & Total & Percentage \\
\hline High & $\overline{\mathrm{x}}+$ SD & $\geq 82,60$ & 47 & $15,72 \%$ \\
Middle & $\overline{\mathrm{x}}$-SD $-\overline{\mathrm{x}}+\mathrm{SD}$ & $68,23-82,59$ & 208 & $69,18 \%$ \\
Low & $\overline{\mathrm{x}}$-SD & $\leq 68,22$ & 45 & $15,09 \%$ \\
\hline Total & & & 300 & $100 \%$ \\
\hline
\end{tabular}

Based on table 3, it is known that respondents with high thinking critical were 47 people $(15.72 \%)$, respondents with critical thinking were as much as $208(69.18 \%)$, and respondents with low critical thinking were 45 people $(15.09 \%)$.

Furthermore, based on the results of the Chi Square Test, it is known that the gender of the respondent did not play a significant role in determining the level of moral disengagement because the $\mathrm{p}$ value $=0.811>0.05$. While the age of the respondent plays a significant role in increasing or decreasing critical thinking because the value of $\mathrm{p}=0.027<0.05$. The origin of the school does not have a significant role in raising and decreasing critical level because the $\mathrm{p}$ value $=0.539<0.05$. There is a significant level of semester in increasing and decreasing critical thinking because the $\mathrm{p}$ value $=0.037$ $<0.05$. However, the origin of faculty does not play a significant role in increasing and decreasing the moral disengagement of respondents because the value of $p=0.207>$ 0.05 .

\section{Moral disengagement}

Based on the results of the study, the following can be described the moral disengagement variable that the average value of the moral disengagement variable is 84.75 , median 85 , mode 78 , standard deviation 10.49 , variant 109.98 , minimum value 48 and maximum value 115 . Next to determine the high and low moral scores of respondents, researchers make norms with three categories as follows:

Table 4

Categorization of Moral Disengagement

\begin{tabular}{lllll}
\hline Category & Criteria & Score & Total & Percentage \\
\hline High & $\bar{x}+$ SD & $\geq 95,24$ & 47 & $15,72 \%$ \\
Middle & $\bar{x}-S D-\bar{x}+$ SD & $74,27-95,23$ & 205 & $68,24 \%$ \\
Low & $\bar{x}-$ SD & $\leq 74,26$ & 48 & $16,04 \%$ \\
\hline Total & & & 300 & $100 \%$ \\
\hline
\end{tabular}


Based on table 4, it is known that respondents with a high moral disengagement were 47 people $(15.72 \%)$, respondents with a moderate moral disengagement were 205 (68.24\%), and respondents with a low moral disengagement were 48 people $(16.04 \%)$

Furthermore, based on the results of the Chi Square Test, it is known that the sex of the respondent did not play a significant role in determining the height of moral disengagement because the $p$ value $=0.074>0.05$, as well as the age of respondents did not play a significant role in increasing or decreasing moral disengagement because $\mathrm{p}=$ $0.356>005$, while the origin of the school has a significant role in increasing and decreasing moral disengagement because the $\mathrm{p}$ value $=0.013<0.05$. There is no significant level of semester in raising and decreasing moral disengagement because the $\mathrm{p}$ value $=0.609>0.05$, as well as the origin of faculty does not play a significant role in increasing and decreasing the moral disengagement of respondents because the $p$ value $=0.97>0.05$.

\section{Model Analysis Results}

The test results of the structural models that the researchers conducted using the Structural Equation Model (SEM) with the help of software lisrel 8.7 software obtained the fit index as follows:

Table 5

Model Fit Index

\begin{tabular}{lrrc}
\hline Fit index & Fit Score & Criteria & Conclusion \\
\hline Root Mean Square Error of Approximation (RMSA) & 0,067 & $<0,08$ & fit \\
Goodness of Fit Index (GFI) & 0,91 & $>0,90$ & fit \\
Non-Normed Fit Index (NNFI) & 0,91 & $>0,90$ & fit \\
Comparative Fit Index (CFI) & 0,93 & $>0,90$ & fit \\
Incremental Fit Index (IFI) & 0,93 & $>0,90$ & fit \\
\hline
\end{tabular}

From Table 5, it is known that all of indexes is fit. Therefore, the model in this study was declared fit. Thus, it can be concluded that the theoretical model about the influence of internal locus of control on moral disengagement with critical thinking as mediator fit with empirical data.

\section{Results of structural model analysis}

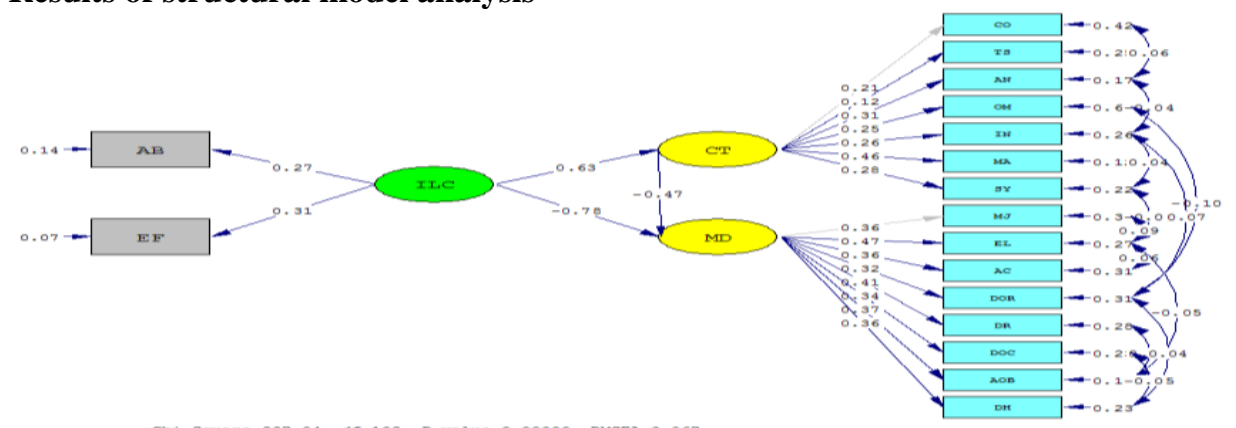

Figure 1

The Structural Model Test Results 
Based on the figure 1 show that direct effect of internal locus of control on critical thinking has a positive and significant effect with $\gamma$ value $=0.63$ and $t_{\text {count }}: 4.16>t_{\text {table }}$ : 1.65. Figure 1 also shows that internal locus of control has a negative and significant effect on moral disengagement with $\gamma$ value $=-0.78$ and $t_{\text {count }}:-4.90>t_{\text {table }}: 1.65$. And critical thinking has a negative and significant effect on moral disengagement with $\gamma$ value $=-0.47$ and $t_{\text {count }}: 2.76>t_{\text {table }}: 1.65$. while the structural model of indirect effect of internal locus of control on moral disengagement mediated by critical thinking shows that $\gamma$ value $=-0.78$ with $t_{\text {count }}-5.26>t_{\text {table }}: 1.65$.

\section{DISCUSSION}

Based on the results of model testing, it is known that the theoretical model of the influence of internal locus of control on moral disengagement is mediated by fit thinking with empirical data. According to Joreskog and Sorborm (1996) what is meant by model compatibility is the suitability between the sample covariance matrix and the estimated population covariance matrix produced, in general it can be explained that the diversity in the sample is appropriate or repetitive with the diversity that exists in the population. This means that the diversity that occurs in students who are used as research samples is in accordance with the diversity of all UIN Sunan Gunung Djati Bandung students who live in boarding schools. Thus, the theoretical model that researchers offer can be used as a model of analysis in analyzing the moral disengagement that occurs among students, especially students of Sunan Gunung Djati UIN Bandung who live in boarding schools around the campus.

The results of this study also prove that internal locus of control has a positive and significant effect on critical thinking in students of Sunan Gunung Djati UIN Bandung who live in Islamic boarding schools around campus. The results of this study reinforce the results of the research of Oğuz and Sariçam (2016) which found that external locus of control was negatively significant with critical thinking and also show that critical thinking dispositions shows an increase while the internal locus of control level increases. This study shows that internal locus of control has an important role in improving critical thinking skills in someone, this is because individuals who have a high internal locus of control is a hard worker who continues to try to resolve the problems faced and always try to think effectively.

Crider (1983) also revealed that individuals with high internal locus of control have individuals who like to work hard, have high initiatives, always try to find solutions to problems, always try to think as effectively as possible, always have a perception that effort must be made if desired succeeded. Efforts to continue to be able to solve problems and keep trying to think effectively have a positive impact on the formation of critical thinking skills. Because effective problem-solving abilities and effective ways of thinking can encourage the formation of systematic thinking that is characteristic of critical thinking. The ability to solve problems effectively also encourages a person to improve their analytical thinking skills and think more deeply.

Based on the results of the study, it is known that internal locus of control has a negative and significant effect on moral disengagement in students of Sunan Gunung Djati UIN 
Bandung who live in Islamic boarding schools around campus. This study reinforces the O'Fallon and Butterfield (2005) study which found that individuals with internal locus of control tend to show intentions to behave unethically but are more likely to show an intention to behave ethically. Individuals with internal locus of control are also more likely to behave ethically because they are people who like to work hard, have high initiative, always try to find problem solving, always try to think as effectively as possible, always have a perception that effort must be made if they want to succeed (Crider 1983).

According to Kreitner \& Kinicki (2009) individuals who have an internal locus of control tendency are individuals who have the confidence to be able to control all events and consequences that have an impact on their lives. Whereas according to Hanurawan (2010) people with internal locus of control are very suitable for occupying positions that require initiative, innovation, and behavior initiated by oneself such as researchers, managers or planners.

According to Robbins and Judge (2007) internal locus of control are individuals who believe that they are the holders of control over whatever happens to them. Individuals with internal locus of control have a perception that the environment can be controlled by themselves so that they are able to make changes according to their wishes. Individual internal factors which include work ability, personality, work actions related to work success, self-confidence and failure of individual work are not caused due to relationships with work partners. Internal oriented individuals are more active and always try to master the life they live compared to external oriented individuals.

The results of this study also found that critical thinking had a negative and significant effect on the diversity of morals in UIN students at Sunan Gunung Djati Bandung who lived in Islamic boarding schools around campus. The results of this study reinforce the results of experimental studies conducted by Bustamante and Chaux (2014) that critical thinking is one of the factors that can reduce moral disengagement. O'Hare (2004) states that individuals who think critically have the characteristics of confidence in thinking, have a strong desire to seek truth, be honest and objective in thinking, analytical thinking skills, open thinking, have a desire to know and understand things in depth, mature in thinking, and able to think systematically.

Individuals who have the desire to seek the truth are very unlikely to commit acts that violate the ethics and social norms that have been agreed upon. Honesty and objectivity in thinking can also encourage individuals to avoid and leave deeds that are not approved by social norms. The desire to know and understand in depth a case can also encourage individuals to think and behave carefully so that their behavior does not violate the prevailing norms in the environment.

According to Dacey and Kenny (in Desmita 2010), critical thinking is "The ability to think logically, to apply this logic to thinking of assessment, and to make good judgments and decisions". which means the ability to think logically, and apply it to assess situations and make good decisions. According to Suryosubroto (2009) critical thinking is a mental process for analyzing information obtained. This information is 
obtained through observation, experience, communication, or reading. According to Johnson (2009) critical thinking is defined as thinking to systematically investigate the thinking process itself.

The ability of people to think critically can be able to reduce moral disengagement because critical thinking is the ability to think systematically which includes identifying, analyzing, and evaluating information to be applied in decision making. The process of identifying, analyzing and evaluating information from this environment makes individuals not easy to carry out behaviors that violate legal norms.

This study also found that critical thinking is a mediator variable which plays a significant role for the influence of concern for other, perspective taking and internal locus of control on moral disengagement in students of Sunan Gunung Djati UIN Bandung who live in Islamic boarding schools around the campus environment. The results of this study reinforce the results of experimental studies conducted by Bustamante and Chaux (2014) which resulted that critical thinking is one of the factors that can reduce moral disengagement. According to O'Hare (2004) critical thinking individuals have the characteristics of having high self-confidence in thinking, having the desire to seek truth, honest and objective in thinking, having analytical thinking skills, open minded patterns, having the desire to know and understand something deep, mature in thinking, and able to think systematically.

Individuals who have the desire to seek the truth are very unlikely to commit acts that violate the ethics and social norms that have been agreed upon. Honesty and objectivity in thinking can also encourage individuals to avoid and leave deeds that are not approved by social norms. The desire to know and understand in depth a case can also encourage individuals to think and behave carefully so that their behavior does not violate the prevailing norms in the environment.

Based on the results of statistical tests, it is known that the factor loading value of the indirect effect of exogenous variables on endogenous variables is greater than the direct effect. This shows that the role of mediator variables really reinforces the influence of exogenous variables on endogenous variables. Thus, it is true what the researchers suspect is that the inconsistency of the concern variables for other, perspective taking, and internal locus of control is not consistent with moral disengagement because there are other important variables that should be used as reinforcement variants so that the influence is consistent, namely critical thinking.

\section{CONCLUSION}

This study found that the theoretical model of the influence of internal locus of control on moral disengagement is mediated by critical thinking fit (suitable) with empirical data. Critical thinking acts as a significant mediator on the influence of internal locus of control on the moral disengagement of students at Sunan Gunung Djati UIN Bandung who live in boarding schools around campus. Critical thinking and internal locus of control have a negative and significant effect on the moral disengagement of UIN Sunan Gunung Djati Bandung students who live in boarding schools around the campus. 


\section{REFERENCES}

Aprilia, \& Solicha. (2012) Faktor-faktor yang mempengaruhi moral disengagement Remaja. TAZKIYA: Jurnal Psikologi. 18(1), 1-17. doi: 10.15408/tazkiya.v18i1.9236

Bandura, A. (1999) Self-efficacy in changing societies. US: Cambridge University.

Bandura, A. (2016) Moral disengagement (how people do harm and live with themselves). New York: Worth Publishers Macmillan Learning.

Bustamante, \& Chaux. (2014). Reducing moral disengagement mechanisms: A comparison of two interventions. Journal of Latino/Latin American Studies, 6(1), 52-63.

Caravita, S. C. S., Blasio, P. D., Salmivalli, C. (2008). Unique and interactive effects of empathy and social status on involvement in bullying. Social Development, 18(1), 140163. doi: 10.1111/j.1467-9507.2008.00465.x.

Cherry, J. (2006) The impact of normative influence and locus of control on ethical judgments and intentions: A cross-cultural comparison. Journal of Business Ethics, 68(2), 113-132. doi: 10.1007/s10551-006-9043-3.

Chiu, R. K. (2003) Ethical judgment and whistleblowing intention: Examining the moderating role of locus of control. Journal of Business Ethics, 43(1-2), 65-74. doi: 10.1023/A:1022911215204.

Crider, A. B. (1983) Psychology. Scott, Foresman \& Company.

Desmita. (2010) Psikologi perkembangan peserta didik. Bandung: PT. Remaja Rosdakarya

Detert, J. R., Trevino, L. K., \& Sweitzer, V. L. (2008) Moral disengagement in ethical decision making: A study of antecedents and outcomes. Journal of Applied Psychology, 93(2), 374-391. doi: 10.1037/0021-9010.93.2.374.

Edwards, P. (1967) Alam Pikiran Yunani, Tirtamas, Jakarta.

Facione, P. A., Facione, N. C., \& Giancarlo, C. A. (2000). The California critical thinking disposition inventory; Test manual: 2000 update. Millbrae, CA: California Academic Press.

Fida, R., Tramontano, C., Paciello, M., Guglielmetti, C., Gilardi, S., Probst, T. M., \& Barbaranelli, C. (2018). 'First, do no harm': The role of negative emotions and moral disengagement in understanding the relationship between workplace aggression and misbehavior. Frontiers in Psychology, 9: 671. doi: 10.3389/fpsyg.2018.00671.

Hanurawan, F. (2010) Psikologi sosial. Bandung: Remaja Rosdakarya

Hazlitt, H. (2003). Dasar-dasar moralitas. Yogyakarta: Pustaka Pelajar.

Halpern, D. F., \& Marin, L. M. (2011) Pedagogy for developing critical thinking in adolescents: Explicit instruction produces greatest gains. Thinking Skills and Creativity, 6(1), 1-13. doi: 10.1016/j.tsc.2010.08.002.

Hill, R. (2011) Teach internal locus of control. Beach Haven NJ: Power Press. 
Hsu, W. T., \& Pan, Y. H. (2018). Moral disengagement and student misbehavior in physical education, Journal of Sports Science and Medicine, 17, 437-444

Huky, W. (1982) Pengantar sosiologi. Usaha Nasional. Surabaya.

Hyde, Shaw, \& Moilanen (2010) Developmental precursors of moral disengagement and the role of moral disengagement in the development of antisocial behavior. Journal Abnorm Child Psychol, 38(2), 197-209.

Iwai, T., Carvalho, J. V. F., \& Lalli, V. M. (2018). Explaining transgressions with moral disengagement strategies and their effects on trust repair. Brazilian Administration Review, 15(4), 1-23.

Johnson, R., \& Taylor, W. (2010) Buku ajar praktik kebidanan. Jakarta: EGC.

Johnson, E. B. (2009). Contextual teaching and llearning: Menjadikan kegiatan belajar mengajar mengasyikkan dan bermakna. Bandung: Mizan Learning Center.

Jolliffe, D., \& Farrington. D. P. (2006). examining the relationship between low empathy and bullying. Aggressive Behavior, 32, 540-550. doi: 10.1002/ab.20154.

Joreskog, K. G., \& Sorborm, D. (1996) Lisrel 8: User reference guide. Chicago: Scientific Software International.

Kargar, F. R., Ajilchi, B., Choreishi, M. K., \& Zangene, Z. Z. (2012) the effect of teaching critical and creative thinking skills on the locus of control and psychological well-being in adolescents. Procedia - Social and Behavioral Sciences, 82, 51-56.

Karimi, \& Alipour. (2011) Reduce job stress in organization: Role of locus control. International Journal of Business and Social Science, 2(18), 232-236.

Kreitner, R., \& Kinicki, A. (2009) Perilaku organisasi. Jakarta. Salemba Empat.

Loghmani, H. (2010). The effect of critical thinking skill teaching on locus of control and cognitive inconsistency (Unpublished master thesis). Payam Noor University of Tehran, Iran.

Moore, C., Detert, J. R., Treviño, L. K., Baker, V. L., \& Mayer, D. M. (2016). "Why employees do bad things: Moral disengagement and unethical organizational behavior": Corrigendum. Personnel Psychology, 69(1): 307. doi: 10.1111/peps.12137

O'Fallon, M. J., \& dan Butterfield, K. D. (2005) A review of the empirical ethical decision-making literature: 1996-2003. Journal of Business Ethics, 59, 375-413.

Ogunyemi, K (2013) Ethics education and locus of control: Is Rotter's scale valid for Nigeria? African Journal of Business Ethics, 7(1), 1-11. doi: 10.4103/18177417.119951.

Oğuz, A., \& Sariçam, H. (2016) The relationship between critical thinking disposition and locus of control in pre-service teachers. Journal of Education and Training Studies, 4(2), 182-192. doi: 10.11114/jets.v4i2.1196.

O'Hare, L. (2004) Measuring critical thinking skills and dispositions in undergraduate students (Unpublished doctoral dissertation). Queen's University Belfast, UK. 
Robbins dan J. (2007) Perilaku organisasi. Jakarta. Salemba Empat.

Rotter, J. B. (1966). Generalized expectancies for internal versus external control of reinforcement. Psychological Monographs: General and Applied, 80(1), 1-28. doi: 10.1037/h0092976.

Saracaloğlu, A. S., \& Yılmaz, S. (2011). An investigation of prospective teachers' critical thinking attitudes and locus of control. Elementary Edu. Online, 10(2), 468-478.

Seifert, K. L. \& Hoffnung, R. J. (1994). Child and adolescent development. Boston: Houghton Mifflin.

Özkahraman, Ş., \& Yıldırım, B. (2011). An overview of critical thinking in nursing and education. American International Journal of Contemporary Research, 1(2), 190-196.

Sigelman, Carol, K. R., \& Elizabeth. (2003). Life span human development. Belmont California: Wadsworth.

Sternberg, R. J. (1994). Encyclopedia of human intelligence. New York: Macmillan.

Suryosubroto. (2009). Proses belajar mengajar di sekolah. Jakarta. Renika Cipta.

Suseno, F. M. (1998). 13 Model pendekatan etika bunga rampai teks - teks etika, dari plato sampai dengan nietzhe. Yogyakarta: Kanisius.

Tillman, C. J., Gonzalez, K., Whitman, M. V., Crawford, W. S., \& Hood, A. C. (2018) A multi-functional view of moral disengagement: Exploring the effects of learning the consequences. Frontiers in Psychology, 26(8): 2286. doi: 10.3389/fpsyg.2017.02286.

Trevino, L. T., Weaver, G., \& Reynolds, S. J. (2006). Behavioral ethics in organizations: A review. Journal of Management, 32, 951-990.

Trice, A. (2013) A revision of the academic locus of control scale for college students. Perceptual and Motor Skills, 116(3), 817-829. doi: 10.2466/08.03.PMS.116.2.

Tsai, J., Wang, C., \& Lo, H. (2014) Locus of control, moral disengagement in sport, and rule transgression of athletes. Social Behavior and Personality: An international journal, 42(1), 59-68. doi: 10.2224/sbp.2014.42.1.59

Wang, F. M., Chen, J. Q., Xiao, W. Q., Ma, Y. T., \& Zhang, M. (2012) Peer physical aggression and its association with aggressive beliefs, empathy, self-control, and cooperation skills among students in a rural town of China. Journal of Interpersonal Violence, 27(16), 3262-3267. doi: 10.1177/0886260512441256.

Wang, X., Lei, L., Yang, J., Gao, L., \& Zhao, F., (2016) Moral disengagement as mediator and moderator of the relation between empathy and aggression among Chinese male juvenile delinquents. Journal Child Psychiatry Hum Dev., 48(2), 316-326. doi: 10.1007/s10578-016-0643-6. 